\title{
Tri-dimensional measurements to evaluate dimensional alterations in gypsum patterns for complete dentures
}

\section{Medição tridimensional para avaliar alterações dimensionais em modelos de gesso para próteses totais}

Wildes da Costa MONTEIRO

Professor - Dental School of University of Itaúna

Christiano Alves de Lima CORRADI

Industrial Mechanical Engineer - SENAI/CETEF

Saide Sarckis DOMITTI

Professor of Prosthodontics - Dental School of Piracicaba - UNICAMP

Simonides CONSANI

Professor of Dental Materials - Dental School of Piracicaba - UNICAMP

\begin{abstract}
The use of machines to measure specifics points in the patterns, these points transference to a tri-dimensional design program and the areas math calculation, by the solids produced in that program are an efficient alternative to verify and after compare the dimensional variations that occurs in gypsum patterns, related of the moulding materials. The use of this technology was fundamental for determinating dimensional variation's accuracy, that in most case are too acute and hard to be determinated and compared. The present paper proved how important is the use of method to get tri-dimensional points, to obtain the respectives digital solids and areas and volumes calculation by finite element method. These concepts are important, since they strongly contribute for the result accuracy about dimensional variation, as mathematic treatment was made in three dimensions (breadth, length and height) on the pattern in study.
\end{abstract}

\section{UNITERMS}

Calcium sulfate, moldes; method, finite element; techniques, measures

\section{INTRODUCTION}

There are many methods to check the results of researches that analyze dimensional variation in different kinds of moulding materials and their respectives die. Among these methods can be stood out sliding caliper use in measurement of dimensional variation in reversible hydrocolloids (VIEI$\mathrm{RA}^{11}, 1976$ ), confronter micrometer used in determinating acrylic resin dimensional variation (GABERLINI ${ }^{5}$, 1996), confronter optical microscope to verify gypsum molds behavior, made in Silicone molds per addiction, polyether, polysulphide, Silicone per condensation and irreversible hydrocolloids $\left(\mathrm{COELHO}^{4}, 1997\right)$, profile projector to check the dimensional variation in gypsum patterns related to moulding materials and disinfecting solutions (VERGANI ${ }^{9}, 1998$ ).

Furthermore, dimensional variations in gypsum and trochees accuracy were verified in a comparative dimensional analyses between the sectioned and the intact pattern by reference points measured with an enlighten microscope, turning round the patterns in a math way (SERRANO et al. $\left.{ }^{8}, 1998\right)$. It were verified the dimensional variation that occur in a complete denture after processing and clinical remounting were measured with a digital sliding caliper (MONTEIRO ${ }^{7}, 2000$; CARVALHO et al. ${ }^{3}, 2001$; BARBOSA et al. ${ }^{2}$, 2002).

Molds rebasing gotten by frozen acrylic resin moulding technique and conventional moulding by 
filled headgear with mercaptan were dimensionally checked with deep microscope (MONDELI et al. ${ }^{6}$, 2000), when the variation in implants analogous inclinations were checked with profiler (ASSUNÇÃ O $\left.{ }^{1}, 2001\right)$.

The purpose of this study was to verify the dimensional variations that occur in plaster molds used to construction of complete dentures, by tridimensional design gotten from mathematical calculations.

\section{Material AND MEthod}

It was made stone casts from silicone, compound modelling with alginate and alginate molds obtained from a metallic aluminum standard pattern. It were set in metallic standard pattern seven screws as referential points to the linear measurations, to obtain areas and volumes that would be calculated by a tri-dimensional software. The coordinates tri-dimensional measurations were made in type IV stone casts (Figure 1) and in the aluminum standard pattern.

A tri-dimensional measurement equipment (Mitutoyo, model BLN 710) fitted out with measurement head Renishaw PH9 and searcher TP 200 with $1 \mathrm{~mm}$ diameter were used to accomplish the measurements. Tri-dimensional measurement machines are equipments used to measure the geometry area with good versatility and accuracy. This

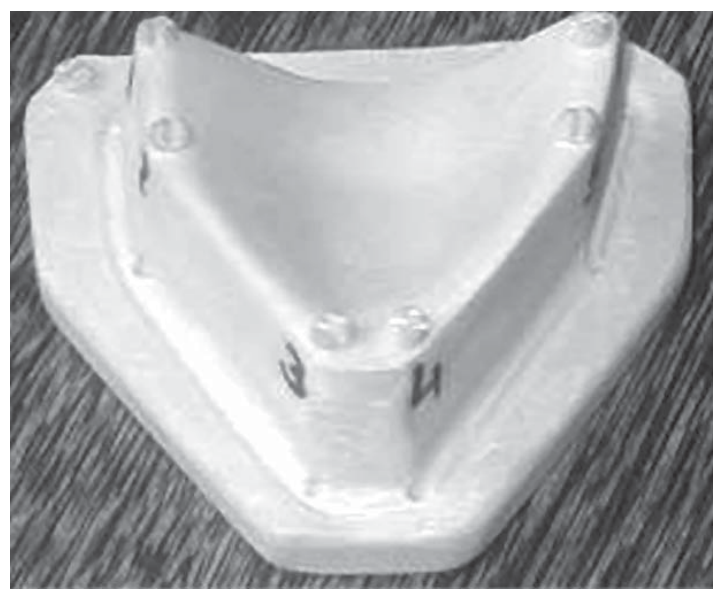

FIGURE 1 - Stone cast (Frontal view). equipment associated with CAD (Computer Aided Design) systems permit the determination of $\mathrm{X}, \mathrm{Y}$, $\mathrm{Z}$ coordinates or Cartesian axes, that permit to get all the geometry dimensions (VICENTE ${ }^{10}, 2000$ ).

A coordinate measurement machine is a mechanical and electronic system, which objective is the obtainment of Cartesian coordinates of points on solid surfaces. It's constituted for a stable and fixed base over that it's assembled the three basics components of its structure that are normally the measure table, the colonnade and the arm. In the arm, in other words, on the side external inferior of the vertical axis ( $Z$ ) a special sensor is coupled (mechanic, electronic or optical) that will enter in contact with the piece that will be measured, being moved in agreement with the capacity of the machine. The sensor more used now is the electronic sensor. These sensors are units of very sensitive searching, electronically linked to the digital accountants. When doing contact with the piece that will be measured, the measurement tip moves at an angle and it produces an electric and acoustic sign that freezes the digital indication, showing the value of the coordinate of sensor's position. When data processing systems are used, that sign allows that the computer analyzes the suitable value in the digital accountant. When the system of registration of data is worked, the reading of coordinates is made automatically in three graduate lineal scales that are associated respectively each one of the components that materialize the reference axes. Usually, the registration system is worked mechanically, for the touch of the location mechanism on the surface of the object for measurement. However, there are other registrations systems that are worked by optical systems of location, now just as laser beams contemplated in the surface of the object, avoiding like this the contact with the same. The readings about the lineal scales are still submitted to several corrections, with the objective of eliminating due mistakes, not only to defects of construction of the machine, but also to the variation of the environmental conditions and the other possible specific characteristics (VICENTE ${ }^{10}$, 2000).

The movement of each axis is registered by an electronic reading system shown in a digital monitor. In general, the machine is linked to a computer that, besides playing an essential part in the phase of processing of the coordinates, it can still control the equipment during the acquisition of the 
coordinates. These machines execute the measurement of coordinates according to a process directly based in the concept of system of coordinates in the space. That system of coordinates is materialized by the structure of the machine and for the movement of their components. The dimensional definition of a piece is made geometrically in the three-dimensional space. Three perpendicular axes amongst themselves, calls $\mathrm{X}, \mathrm{Y}$ and $\mathrm{Z}$ that define a coordinated system of three dimensions characterize those spaces. So, a point in the space is projected in the reference plan, where two coordinates are defined $(\mathrm{X}, \mathrm{Y})$ and the glide $(\mathrm{Z})$ corresponds to the perpendicular height (VICENTE $\left.{ }^{10}, 2000\right)$.

For the accomplishment of the three-dimensional measurements, they were positioned screws that, later, they were identified with numbers (Figure 2).
For the accomplishment of this work, the stone casts were fastened in the base or measurement table. The collection of the coordinates of the points of the center of each screw were accomplished (Figure 3).

Starting from the coordinates collected in the three-dimensional measurement, the designs of the illustrations were generated, where the measurements and calculations for each model would be accomplished. The amount of collected coordinates was similar for all stone casts.

The drawings of each cast were generated through the manual transfer of the coordinates for the program of three-dimensional design Mechanical Desktop, where the mathematical calculation of the volumes and subsequent determination of the areas was accomplished, through the mathematical method for finite elements (Figure 4).

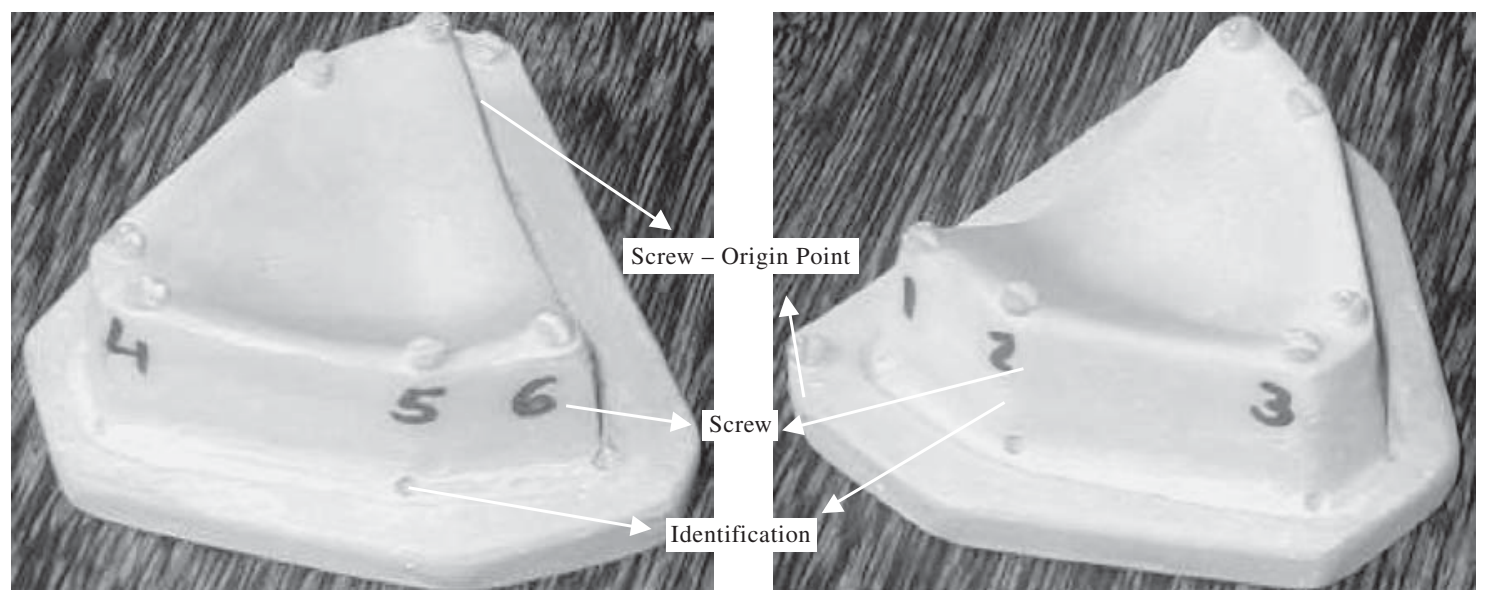

FIGURE 2 - Stone cost with identified screws: a) right; b) left.

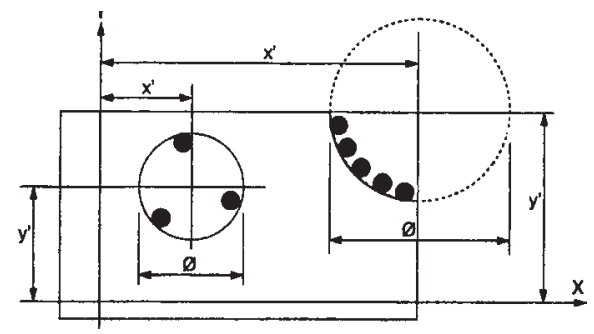

FIGURE 3 - Points for data collected. 
After the transfer of the coordinates, it was accomplished the design of the illustration that best represented the areas of each stone cast to be made calculations. For the determination of each illustration, the points regarding each coordinate were linked through lines and specific arches (Figure 5).

The segments that linked a point in another were identified, for the accomplishment of its posterior measurement (Figure 6).

With the certain illustrations of each model, the extrusion of the area of each illustration was ac-

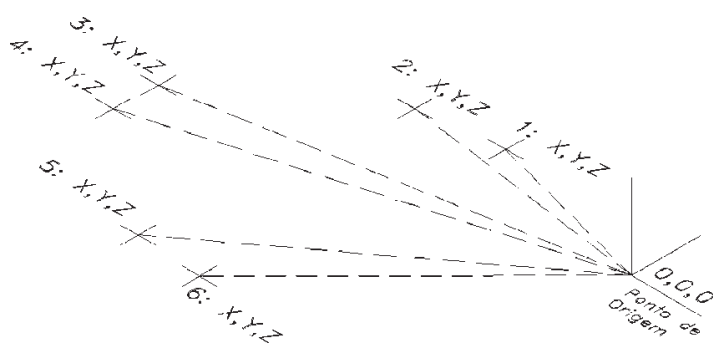

FIGURE 4 - Coordinates $\mathrm{X}, \mathrm{Y}$ and $\mathrm{Z}$ - software mechanical desktop.

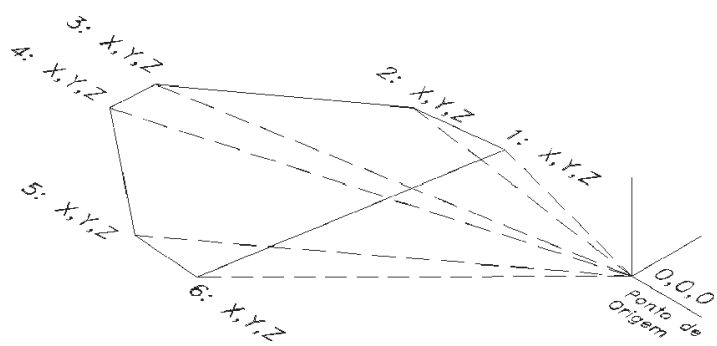

FIGURE 5 - Picture generation for gotten coordinates X, Y and Z. complished, with a fixed height of $10 \mathrm{~mm}$. The objective of this procedure is the construction of a solid starting from the projected area of each illustration (Figure 7).

The solids of each illustration were built through the mathematical method for finite elements (Figure 8).

Once certain the volume of the solid, took place the division of this volume for the height standard of $10 \mathrm{~mm}$, used for extrusion of each illustration, this way, being determined the area of the illustration that generated the solid.

\section{Results}

After the accomplishment of the measurements of each segment and of the calculation of the each illustrated areas, for each type of molding material, three spreadsheets were accomplished for statistical control of the variables.

The values in absolute percentage (value always positive) of the variation of the coordinates $\mathrm{X}, \mathrm{Y}$ and $\mathrm{Z}$, of the lengths of each continuation and of the area of each illustration, for each group of five models of the materials Alginate, Silicone and Compound Modelling and Alginate, in relation to the standard pattern.

The Table 1 shows the average of the coordinates $\mathrm{X}, \mathrm{Y}$ and $\mathrm{Z}$, of the length and of the area, in absolute percentage for each material.

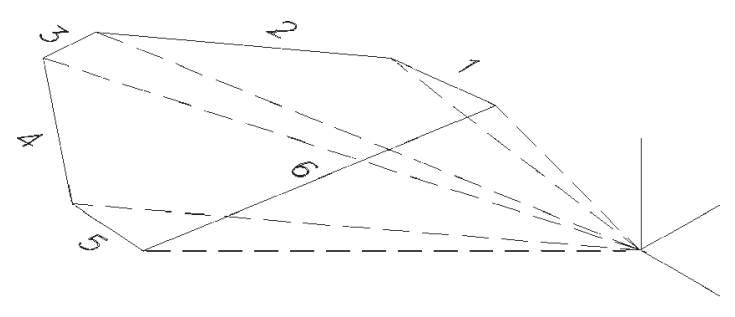

FIGURE 6 - Identification of the segments in the gotten figure. 

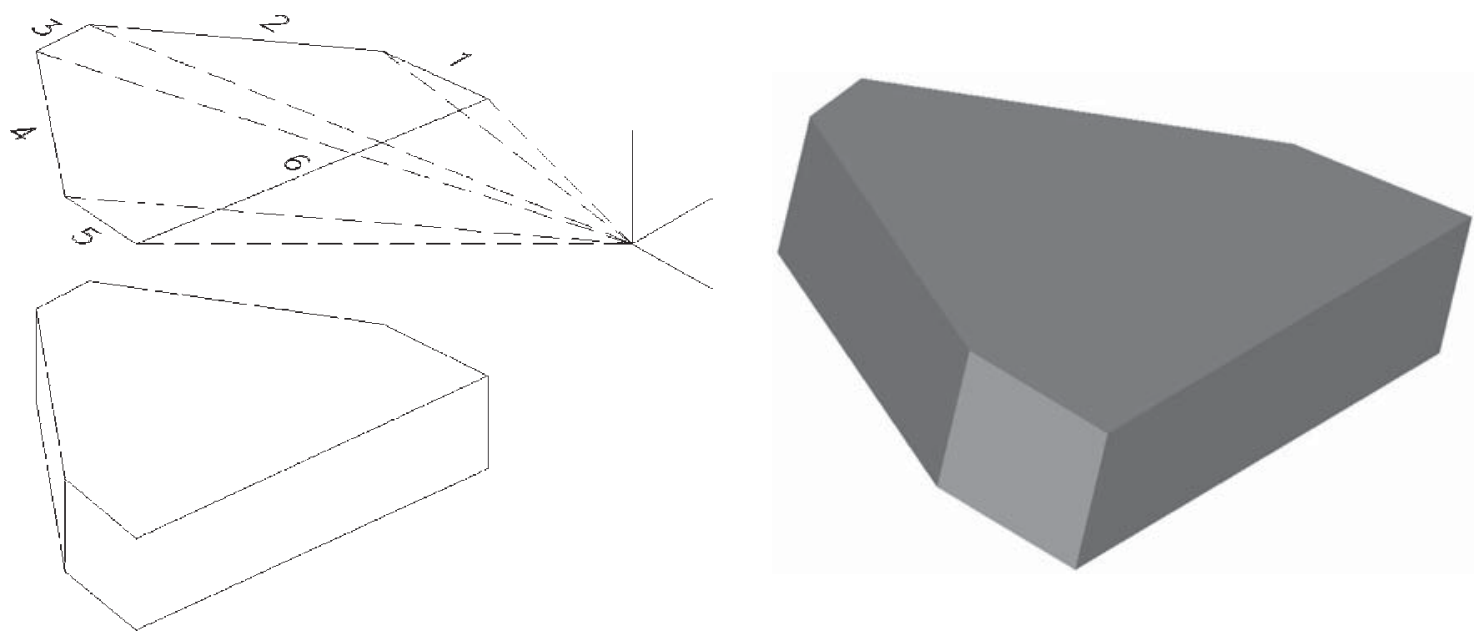

FIGURE 7 - The construction of a solid starting from project area: a) solid extrusion with standard; b) gotten solid after extrusion.

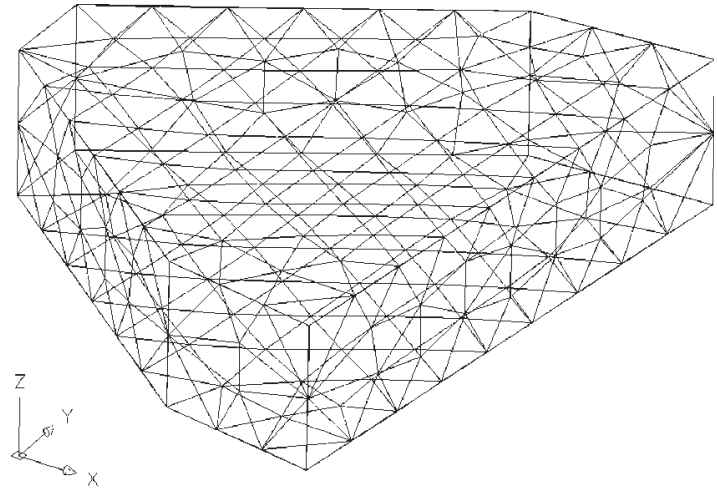

FIGURE 8 - 3D solid (finite element calculation).
Being used the Table 1, thes graphs presented in Figures 5, 6 and 7 was accomplished, representing all of the dimensional variations found for each material. For the determination of the obtained dimensional accuracy, the average of the coordinates $\mathrm{X}, \mathrm{Y}$ and $\mathrm{Z}$ was accomplished of each material identified as positioning. The positioning means the average in percentage, of the dimensional variation of each group of five models of the materials Alginate, Silicone and Compound Modelling and Alginate. Then, the graph presented Figure 5 was accomplished, representing the dimensional variations found in relation to the positioning, to the length and the area for each material.

As it can be seen in the graphs (Figures 5 and 6 ), the moulding material that presented least dimensional variations, in other words, a best dimensional exactness in the generated patterns was Silicone, after Compound Modelling and Alginate, and Alginate. 
Table 1 - Average of the coordinates $X, Y$ and $Z$, length, area and positioning

\begin{tabular}{|c|c|c|c|c|c|}
\hline Medium & $\% \mathbf{X}$ & $\begin{array}{c}\% \mathrm{Y} \\
\text { Positioning }\end{array}$ & $\% \mathbf{Z}$ & \% Comp. & $\%$ Area \\
\hline \multirow[t]{2}{*}{ Alginate } & $6,642 \%$ & $9,650 \%$ & $10,332 \%$ & \multirow{2}{*}{$0,683 \%$} & \multirow{2}{*}{$0,753 \%$} \\
\hline & $8,875 \%$ & & & & \\
\hline \multirow[t]{2}{*}{ Silicone } & $10,539 \%$ & $10,083 \%$ & $2,867 \%$ & \multirow{2}{*}{$0,328 \%$} & \multirow{2}{*}{$0,167 \%$} \\
\hline & $7,830 \%$ & & & & \\
\hline \multirow{2}{*}{$\begin{array}{l}\text { Compound Modelling } \\
\text { and Alginate }\end{array}$} & $8,305 \%$ & $8,101 \%$ & $9,298 \%$ & \multirow{2}{*}{$0,274 \%$} & \multirow{2}{*}{$0,337 \%$} \\
\hline & $8,568 \%$ & & & & \\
\hline
\end{tabular}

\section{Resumo}

Monteiro WC. Medição tridimensional para avaliar alterações dimensionais em modelos de gesso para próteses totais.A utilização das máquinas para medições tridimensionais de pontos específicos nos modelos, a transferência destes pontos para um programa de desenho tridimensional e o cálculo matemático das áreas através dos sólidos gerados deste programa, são uma alternativa eficiente para a verificação e posterior comparação das variações dimensionais nos modelos de gesso, em função dos materiais de moldagem. O uso desta tecnologia fo fundamental para a determinação da precisão das variações dimensionais, que na maioria das vezes são muito pequenas e difíceis de serem determinadas e comparadas. Este trabalho demonstrou a importância da utilização do método de coleta de pontos em coordenadas tridimensionais, da obtenção de sólidos digitais e do cálculo dos volumes e das áreas através do método por elementos finitos. Estes conceitos são importantes, pois, contribuem de maneira significativa para a precisão dos resultados das variações dimensionais, uma vez que o tratamento matemático está sendo realizado nas três dimensões, ou seja, largura, comprimento e altura do modelo de estudo.

\section{UNITERMOS}

Alteração dimensional em modelos de gesso, sistemas de medição.

\section{Conclusion}

The tri-dimensional design method obtained by math calculation is a satisfactory alternative for determination and evaluation of the dimensional alterations that occurs in stone casts. 


\section{References}

1. Assunção W G. Avaliação de moldagens para transferência de implantes ósseo integráveis com angulações diversas. Ribeirão Preto; 2001. [Tese de Doutorado - Faculdade de Odontologia de Ribeirão Preto, USP].

2. Barbosa DB; Compagnoni MA; Leles CR. Changes in occlusal vertical dimension in microwave processing of complete dentures. Braz Dent J 2002; 13(3): 197-200.

3. Carvalho ALA; Compagnoni MA; Barbosa DB. Influência do ciclo de polimerização sobre a dimensão vertical de oclusão em próteses totais. PRG-PósGrad Fac Odontol 2002; 4 (3): 67-73.

4. Coelho A B . Avaliação do comportamento morfodimensional de materiais de moldagem utilizados em implantes dentais. Baurú; 1997. [Dissertação de Mestrado - Faculdade de Odontologia de Baurú, USP].

5. Gaberlini W J. Alterações dimensionais ocorridas com resina acrílica ativadas termicamente após polimerização por três diferentes técnicas mensuradas por dois métodos distintos . Baurú; 1996.
[Dissertação de Mestrado - Faculdade de Odontologia de Baurú, USP].

6. Mondeli J , Soares J C F. Avaliação do reembasamento na moldagem com resina acrílica gelada. Rev Fac Odontol Bauru 2000 8(1-2): 23-9.

7. Monteiro W C . Alteração dimensional na remontagem de prótese total: Estudo Comparativo Utilizando Três Diferentes Materiais. Campinas; 2000. [Dissertação de Mestrado - Faculdade de Odontologia Camilo Castelo Branco].

8. Serrano JG, Lepe X Townsend JD, Johnson G H. Stephen of four removable die systems. J Prosthet Dent 1998; 80(5): 57586.

9. Vergani C E. Influência da desinfecção de moldes na alteração dimensional de modelos de gesso. Rev Odontol Univ São Paulo, 1998 Dez.; 27(2): 381-91.

10. Vicente M A T. Sistema de aquisição de coordenadas. Campinas; 2000. [Apostila - Aula 23 - SENAI].

11. Vieira D F. Bases para aplicação racional dos materiais odontológicos. 2. ed. São Paulo: Atheneu, 1976, 423p.

Recebido em: 14/11/02

Aprovado em: 16/05/03

Dra. Wildes da Costa Monteiro

Rua Rio de Janeiro, 310 Centro CEP: 35500-009 - Divinópolis, MG drawildes@bol.com.b 